\title{
Formulation and Evaluation of Lafutidine Gas Powered System for Controlled Release
}

\author{
N. G. Raghavendra Rao*1, Amrita Bisht ${ }^{2}$ \\ 1. KIET School of Pharmacy, KIET Campus, NCR-Delhi, NH - 58, Meerut Road, Ghaziabad-201206, Uttar Pradesh, India. \\ 2. Department of Pharmacy, GRD (PG) IMT, 214, Rajpur, Dehradun-248009 Uttarakhand, India. \\ *Corresponding author's E-mail: drngraghu@gmail.com
}

Received: 06-11-2020; Revised: 18-12-2020; Accepted: 25-12-2020; Published on: 15-01-2021.

\begin{abstract}
The purpose of this investigation was to prepare Lafutidine Gas Powered System for controlled release. A new drug delivery system of Lafutidine was formulated in an attempt to increase gastric residence time. The gas powered tablets of Lafutidine were prepared by direct compression method using different concentrations of hydrophilic polymers and Trigonella foenum mucilage. FT-IR studies revealed that, there was no incompatibility of the drug with the excipients used. The powder blend was subjected for precompressional parameters. The prepared gas powered tablets were subjected for post-compressional parameters. The results of pre and post compressional parameters were within limit of IP. The combination of sodium bicarbonate and citric acid provided desired floating ability and hence this combination was selected for the formulation of the gas powered tablets. Trigonella foenum mucilage used as release retardant and floating agent when used in combinations with HPMC K4M. The results indicated that Trigonella foenum and HPMC K4M effectively controlled release for $24 \mathrm{hrs}$. All the physicochemical properties were evaluated for all formulation, invitro drug release and in-vitro buoyancy. Floating lag time was observed for all tablets which was less than 15 min and duration of floating tablet was greater than 24 hrs. Floating lag time was observed in best formulations F4, F15 and F16 which shows 24, 22, 21 sec respectively and duration of floating was nearly about $24 \mathrm{hrs}$ and all most $99 \%$ drug released within $24 \mathrm{hrs}$. From the study, it was concluded that the formulation F4, F15 and F16 are most promising gas powered controlled release tablets were floating lag time is very less and duration of floating was nearly about $24 \mathrm{hrs}$. Lafutidine can be developed to increase gastric residence time or the formulation retained for longer periods of time in the stomach and provides controlled release of the drug.
\end{abstract}

Keywords: Lafutidine, FTIR, HPMC K4M, Trigonella foenum mucilage, Carbopol, Gas powered system.

QUICK RESPONSE CODE $\rightarrow$

DOI:

10.47583/ijpsrr.2021.v66i01.019

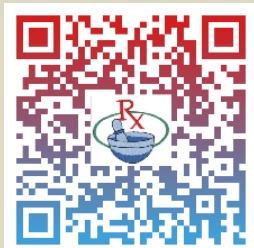

DOI link: $\underline{\text { http://dx.doi.org/10.47583/ijpsrr.2021.v66i01.019 }}$

\section{INTRODUCTION}

$\mathrm{O}$ ral controlled drug release dosage forms have been developed for their huge therapeutic advantages such as formulation fulfil patient compliance and flexibility. The desired region of GI track was due to variable gastric emptying and motility. Short gastric emptying time in human's beings normally averages 2-3 hrs. Through the absorption site, i.e., stomach and upper part of intestine which can result in incomplete drug release from drug delivery system by leading to reduced efficacy of administered dose $^{1}$. A different approaches has been applies to provide predictable, precise and reproducible pattern for controlled release or even site-specific delivery of the drugs $^{2}$. Different approaches are utilized in the prolongation of GRT, includes floating drug delivery systems (FDDS), swelling and the expanding systems, polymeric bio adhesive system, modified-shape systems, high density systems and other delayed gastric emptying system ${ }^{3}$. It has different advantages over immediate release dosage form include the minimization of fluctuations in the drug concentration in plasma and at the site of action prolonged the periods of time, which results the optimized therapeutic effect and reduce side effect, reduction of total dose administered and reduction of administration frequency by leading to improve patient compliances $^{4}$.

Gas powered system (GPS) is one of the Gastroretentive dosage forms which prolong the gastric residence time to achieve the sufficient drug bioavailability. The system mainly floats in gastric fluid because due to of its lower bulk density and compared to that of aqueous medium. It also useful for the drugs which act locally in the proximal part of the GI tract and the drugs those are poorly soluble in intestinal fluid. Since, they have shown to reduce the inter and intra subject variability in drug absorption and to lower the possibility of dose dumping. ${ }^{5}$ These approach have provided a valuable tool to the pharmaceutical company for enhancing the efficiency of delivery of a number of drug molecules. This enhanced commercial gains and expansion of the life cycle of products ${ }^{6}$.

Lafutidine is one of the new $\mathrm{H} 2$-receptor antagonist, after absorption in small intestine, it reach gastric cell by systemic circulation, then directly binds to gastric cell $\mathrm{H} 2-$ receptor results inhibition of gastric acid secretion. It's biological half-life of drug $1.92 \mathrm{hrs}{ }^{7-10}$. The receptor 
binding affinity of Lafutidine is 2-80 times higher than other $\mathrm{H} 2$-receptor antagonists (eg. famotidine, ranitidine and cimetidine $)^{11,12}$.

The present research work was to develop the Lafutidine Gas Powered System for controlled release were prepared by direct compression method using different concentrations of hydrophilic polymers and Trigonella foenum mucilage. A new drug delivery system of Lafutidine was formulated in an attempt to increase gastric residence time.

\section{MATERIALS AND METHODS}

Lafutidine was procured from APCOM Dehradun. Sodium bicarbonate, sodium alginate, carbopol 940 was provided as a gift sample by QualiKem Fine chemicals, Vadodara. Xanthan gum, guar gum, MCC and talc were obtained by Accord Labs, Secunderabad. HPMC was obtained by Astrazenica, Bangalore. Citric acid, magnesium stearate and lactose were obtained by Finar chemicals Ltd, Mumbai. Trigonella foenum was obtained by local market Dehradun.

\section{METHODOLOGY}

\section{Drug and excipients compatibility study:}

FTIR studies: The successful formulation of a suitable and effective solid dosage form depends upon the careful selection of the excipients. Excipients are added to facilitate administration, promote the consistent release and bioavailability of drug. It's necessary to study the compatibility of excipients with drug. Here, IR spectroscopy was used to investigate and predict any physicochemical interaction between components in a formulation and to the selection of suitable compatible Excipients. FTIR studies were conducted and the spectrum was recorded in the wavelength region of 4000 to 400 $\mathrm{cm}^{-1}$. The procedure consisted of dispersing a sample, drug alone and mixture of drug and polymers in $\mathrm{KBr}$ and compressing into discs by applying a pressure of 7 tons for $5 \mathrm{~min}$ in a $\mathrm{KBr}$ pellets. The pellet was placed in the light path and the spectrum was obtained.
Evaluation of pre-compression parameters: Prior to the compression, the formulation powder blends were evaluated for their bulk and tapped density and from these values compressibility index, Carr's index and Hausner's ratio were calculated. While the flow properties of the powder bled were accessed from the angle of repose ${ }^{13-15}$.

\section{Isolation of Trigonella foenum Mucilage ${ }^{16}$}

- 100 gm Trigonella foenum (Fenugreek seeds) were taken.

- Then they were soaked in $600 \mathrm{ml}$ distilled water for duration of $24 \mathrm{hrs}$ in $1000 \mathrm{ml}$ beaker.

- Then Trigonella foenum was grinded in grinder, then that was warmed for 30 mins.

- Finally it was filtered through a muslin bag and squeezed to remove all possible mucilage.

- Equal volume of acetone was added to the above filtrate for the precipitation of mucilage and kept at low temperature (inside a refrigerator) for one day.

- It was dried completely in an incubator at $40-45^{\circ} \mathrm{C}$, finally filtered by using \#80 mesh.

- Trigonella foenum mucilage powder was obtained.

Method of Preparation ${ }^{18-19}$

- Preparation of CGPS tablet of Lafutidine.

- Gas powered tablet of Lafutidine were prepared by direct compression method.

- According to the formula all the ingredients were passed through 60 mesh sieve separately.

- The drug and excipients were mixed and blended in geometrical order to get uniform mixture.

- Tablets were compressed by $8 \mathrm{~mm}$ sizes flat round punch using compression machine.

- The compositions of the CGPS tablet of Lafutidine are given in Table 1.

Table 1: Composition of Lafutidine CGPS Tablet

\begin{tabular}{|c|c|c|c|c|c|c|c|c|c|c|c|c|c|c|c|c|}
\hline Ingredients & F1 & F2 & F3 & F4 & F5 & F6 & F7 & F8 & F9 & F10 & F11 & F12 & F13 & F14 & F15 & F16 \\
\hline Lafutidine & 10 & 10 & 10 & 10 & 10 & 10 & 10 & 10 & 10 & 10 & 10 & 10 & 10 & 10 & 10 & 10 \\
\hline Sodium bicarbonate & 10 & 20 & 30 & 40 & 20 & 30 & 40 & 50 & 40 & 30 & 20 & 30 & 40 & 50 & 50 & 50 \\
\hline Xanthan Gum & 10 & 10 & 10 & 10 & 10 & 10 & 10 & 10 & 10 & 10 & 10 & 10 & 10 & 10 & 10 & 10 \\
\hline Soduim Alginate & 10 & 10 & 10 & 10 & 10 & 10 & 10 & 10 & 10 & 10 & 10 & 10 & 10 & 10 & 10 & 10 \\
\hline HPMC K4M & 50 & 60 & 70 & 80 & - & - & - & - & 70 & 80 & - & - & - & - & 70 & 80 \\
\hline Carbopol 940 & - & - & - & - & 40 & 50 & 60 & 70 & 60 & 70 & - & - & - & - & - & - \\
\hline Trigonella foenum & - & - & - & - & - & - & - & - & - & - & 40 & 50 & 60 & 70 & 60 & 70 \\
\hline Guar gum & 10 & 10 & 10 & 10 & 10 & 10 & 10 & 10 & 10 & 10 & 10 & 10 & 10 & 10 & 10 & 10 \\
\hline MCC & 10 & 10 & 10 & 10 & 10 & 10 & 10 & 10 & 10 & 10 & 10 & 10 & 10 & 10 & 10 & 10 \\
\hline Citric acid & 20 & 20 & 30 & 30 & 20 & 20 & 30 & 30 & 20 & 20 & 20 & 20 & 30 & 30 & 30 & 30 \\
\hline Lactose & 150 & 130 & 100 & 80 & 150 & 130 & 100 & 80 & 40 & 30 & 150 & 130 & 100 & 80 & 20 & 00 \\
\hline Talc & 10 & 10 & 10 & 10 & 10 & 10 & 10 & 10 & 10 & 10 & 10 & 10 & 10 & 10 & 10 & 10 \\
\hline Magnesium stearate & 10 & 10 & 10 & 10 & 10 & 10 & 10 & 10 & 10 & 10 & 10 & 10 & 10 & 10 & 10 & 10 \\
\hline Total & 300 & 300 & 300 & 300 & 300 & 300 & 300 & 300 & 300 & 300 & 300 & 300 & 300 & 300 & 300 & 300 \\
\hline
\end{tabular}




\section{Evaluation of Tablets ${ }^{20}$}

The thickness of the tablets was measured by vernier callipers scale. It is expressed in $\mathrm{mm}$. The hardness of tablet was measured by using the Pfizer hardness tester. The weight of tablets was evaluated on 20 tablets using an electronic balance.

\section{Drug Content ${ }^{21}$}

To evaluate a tablet potential for efficacy, the amount of drug per tablet needs to be monitored from tablet to tablet, and batch to batch. To perform the test, 10 tablets were crushed using mortar pestle. Quantity equivalent to $100 \mathrm{mg}$ of drug was dissolved in $100 \mathrm{ml} 0.1 \mathrm{~N} \mathrm{HCl}$ filtered and diluted up to $50 \mu \mathrm{g} / \mathrm{ml}$, and analyzed spectrophotometrically at 236 $\mathrm{nm}$. The concentration of drug was determined using standard calibration curve.

\section{Buoyancy Capacity $22-24$}

The buoyancy test of tablet was studied by placing them in $200 \mathrm{ml}$ beaker containing $0.1 \mathrm{~N} \mathrm{HCl}$. The time in min taken by the tablet to reach the top from the bottom of the containing/ beaker was floating lag time or FLT and the time for which the tablet continuous floats on the surface of the medium way measured as buoyancy time.

\section{Swelling Characteristics (Water Uptake Study) ${ }^{25}$}

The swelling properties of HPMC and Trigonella foenum containing drug were determined by placing the tablet matrices in the dissolution test apparatus, in $900 \mathrm{ml}$ of distilled water at $37 \pm 0.5^{\circ} \mathrm{C}$ paddle rotated at $50 \mathrm{rpm}$. The tablets were removed periodically from dissolution medium. After draining free from water by blotting paper, these were measured for weight gain. Swelling characteristics were expressed in terms of percentage water uptake (WU \%) according to the equation.

WU $\%$ = Weight of swollen tablet-initial weight of tablet $100 \times$ Initial weight of tablet

\section{In-vitro Dissolution Study ${ }^{26-29}$}

The in-vitro dissolution studied was carried out using USP Dissolution apparatus paddle type at $50 \mathrm{rpm}$. The dissolution medium taken was $900 \mathrm{ml} 0.1 \mathrm{~N} \mathrm{HCL}$ for $24 \mathrm{hrs}$ maintained at $37 \pm 0.5^{\circ} \mathrm{C}$. Adequate of sample $5 \mathrm{ml}$ were withdrawn at specific time interval and drug content was determined spectrophotometrically at $236 \mathrm{~nm}$.

Percentage drug release was calculated using an equation obtained from a standard curve. The graphs of times in hrs vs $\%$ of drug release were plotted. To ascertain the order and mechanism of drug release the in vitro release data was subjected to various kinetic equations.

\section{Treatment of Dissolution Data with Different Kinetic Equations $^{30-32}$}

To analyze the mechanism of release and release rate kinetics of the dosage form, the data obtained were fitted into Zero order, First order, Higuchi matrix, Peppas and. Based on the $r$ - value, the best-fit model was selected.

\section{RESULTS AND DISCUSSION}

\section{Drug excipients compatibility studies-FTIR}

Possible interactions between drug and polymer were investigated by FTIR. FT-IR of pure Lafutidine shown characteristic stretching absorption bands of - $\mathrm{NH}$ group at 3327, of alkene stretching $\left(\mathrm{C}-\mathrm{H}\right.$ and $\mathrm{CH}_{2}$ ) vibration at $2974,2936,2918 \mathrm{~cm}^{-1}$ and alkane stretching

$\left(-\mathrm{CH}_{3},-\mathrm{CH}_{2}\right.$ and $\left.-\mathrm{CH}\right)$ vibration at $2880,2854 \mathrm{~cm}^{-1}$. Also exhibited $\mathrm{C}=\mathrm{O}$ stretch at $1640 \mathrm{~cm}^{-1}$. A selective stretching vibration at $1480 \mathrm{~cm}^{-1}$ and $1462 \mathrm{~cm}^{-1}$ for primary and secondary amine was also observed. For functional groups like SO stretch and -C-S stretch showed vibrations at 1045 and $736 \mathrm{~cm}^{-1}$ respectively.

The IR spectrum of Lafutidine and different excipients clearly indicates that overall there was no alteration in peaks of Lafutidine and different excipients, suggesting that there was no interaction between drug and excipients. (Shown in Fig 1).

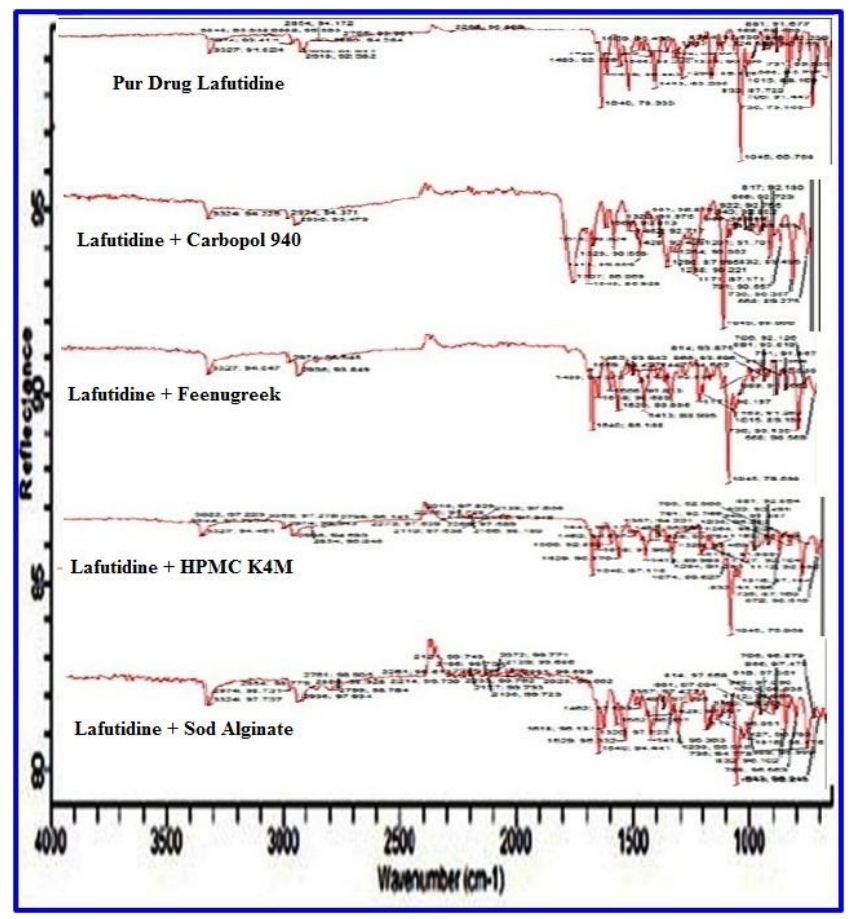

Figure 1: FTIR of Lafutidine, FTIR of Drug + Carbopol 940, Drug + Trigonella foenum, Drug + HPMC K4M and Drug + Sodium Alginate.

\section{Evaluation of Pre-Compressional parameters}

The granulation characteristics are the most important interest to formulation scientist and therefore, most universally measured. These basic measurements of the granulation have been used to develop and monitor the manufacture of many successful pharmaceutical dosage forms. Table 2 depicts the powder blend properties of Lafutidine CGPS tablets. The powder blend was subjected for pre-compressional parameters. The results of precompression parameters were within limit of IP. 
Table 2: Pre-compressional parameters of all the CGPS Lafutidine Formulation.

\begin{tabular}{|c|c|c|c|c|c|}
\hline FC & $\begin{array}{c}\text { Bulk } \\
\text { Density }\left(\mathbf{g m} / \mathbf{c m}^{\mathbf{3}}\right)\end{array}$ & $\begin{array}{c}\text { Tapped } \\
\text { Density(gm/cm }\end{array}$ & Carr's Index & Hausner Ratio & $\begin{array}{c}\text { Angle of Repose } \\
(\boldsymbol{\theta})\end{array}$ \\
\hline F1 & $0.524 \pm 0.05$ & $0.567 \pm 0.02$ & $10.12 \pm 0.02$ & $1.10 \pm 0.03$ & $22.98 \pm 0.19$ \\
\hline F2 & $0.586 \pm 0.07$ & $0.532 \pm 0.05$ & $9.65 \pm 0.04$ & $1.09 \pm 0.05$ & $21.56 \pm 0.18$ \\
\hline F3 & $0.645 \pm 0.02$ & $0.567 \pm 0.04$ & $9.66 \pm 0.02$ & $1.12 \pm 0.08$ & $23.02 \pm 0.13$ \\
\hline F4 & $0.579 \pm 0.06$ & $0.574 \pm 0.07$ & $11.34 \pm 0.06$ & $1.13 \pm 0.04$ & $24.12 \pm 0.16$ \\
\hline F5 & $0.654 \pm 0.04$ & $0.636 \pm 0.03$ & $12.22 \pm 0.05$ & $1.12 \pm 0.06$ & $20.23 \pm 0.18$ \\
\hline F6 & $0.526 \pm 0.08$ & $0.576 \pm 0.09$ & $09.77 \pm 0.03$ & $1.08 \pm 0.08$ & $22.54 \pm 0.13$ \\
\hline F7 & $0.589 \pm 0.07$ & $0.587 \pm 0.07$ & $11.67 \pm 0.07$ & $1.13 \pm 0.05$ & $22.91 \pm 0.18$ \\
\hline F8 & $0.673 \pm 0.06$ & $0.661 \pm 0.05$ & $14.84 \pm 0.04$ & $1.14 \pm 0.08$ & $23.78 \pm 0.16$ \\
\hline F9 & $0.704 \pm 0.02$ & $0.591 \pm 0.03$ & $11.61 \pm 0.06$ & $1.12 \pm 0.03$ & $20.88 \pm 0.17$ \\
\hline F10 & $0.635 \pm 0.09$ & $0.5846 \pm 0.08$ & $13.63 \pm 0.13$ & $1.14 \pm 0.07$ & $24.75 \pm 0.14$ \\
\hline F11 & $0.618 \pm 0.08$ & $0.611 \pm 0.07$ & $12.15 \pm 0.05$ & $1.15 \pm 0.04$ & $23.25 \pm 0.13$ \\
\hline F12 & $0.595 \pm 0.03$ & $0.569 \pm 0.03$ & $13.88 \pm 0.08$ & $1.11 \pm 0.06$ & $22.14 \pm 0.19$ \\
\hline F13 & $0.656 \pm 0.08$ & $0.593 \pm 0.07$ & $14.25 \pm 0.04$ & $1.17 \pm 0.02$ & $25.43 \pm 0.16$ \\
\hline F14 & $0.685 \pm 0.05$ & $0.654 \pm 0.03$ & $12.55 \pm 0.06$ & $1.22 \pm 0.05$ & $27.61 \pm 0.14$ \\
\hline F15 & $0.746 \pm 0.04$ & $0.639 \pm 0.04$ & $12.59 \pm 0.04$ & $1.19 \pm 0.08$ & $26.82 \pm 0.17$ \\
\hline F16 & $0.736 \pm 0.03$ & $0.581 \pm 0.06$ & $13.61 \pm 0.02$ & $1.26 \pm 0.07$ & $24.65 \pm 0.19$ \\
\hline
\end{tabular}

*The values represent mean $\pm S . D ; n=3, F C=$ Formulation Code.

Table 3: Post-compressional parameters of all the CGPS Lafutidine Formulation.

\begin{tabular}{|l|c|c|c|c|c|c|}
\hline FC & Average wt $\mathbf{( m g})$ & Thickness $(\mathbf{m m})$ & Hardness $\left(\mathbf{k g} / \mathbf{c m}^{2}\right)$ & Friability (\%) & Drug content (\%) & Swelling index \\
\hline F1 & $251 \pm 0.03$ & $5.3 \pm 0.03$ & $8.6 \pm 0.04$ & $0.52 \pm 0.013$ & $99.28 \pm 0.55$ & 31.08 \\
\hline F2 & $253 \pm 0.02$ & $5.3 \pm 0.08$ & $6.2 \pm 0.05$ & $0.60 \pm 0.029$ & $98.70 \pm 0.43$ & 34.06 \\
\hline F3 & $248 \pm 0.07$ & $5.3 \pm 0.05$ & $4.2 \pm 0.03$ & $0.48 \pm 0.051$ & $99.06 \pm 0.84$ & 39.95 \\
\hline F4 & $249 \pm 0.04$ & $5.3 \pm 0.07$ & $6.6 \pm 0.07$ & $0.64 \pm 0.035$ & $99.24 \pm 0.55$ & 41 \\
\hline F5 & $252 \pm 0.05$ & $5.3 \pm 0.04$ & $8.4 \pm 0.08$ & $0.71 \pm 0.029$ & $98.50 \pm 0.53$ & 46.03 \\
\hline F6 & $250 \pm 0.06$ & $5.3 \pm 0.06$ & $4.9 \pm 0.02$ & $0.39 \pm 0.042$ & $98.88 \pm 0.31$ & 49.23 \\
\hline F7 & $246 \pm 0.02$ & $5.1 \pm 0.05$ & $6.5 \pm 0.07$ & $0.52 \pm 0.036$ & $99.38 \pm 0.75$ & 50.07 \\
\hline F8 & $255 \pm 0.04$ & $5.1 \pm 0.04$ & $7.2 \pm 0.09$ & $0.658 \pm 0.065$ & $98.62 \pm 0.65$ & 52.3 \\
\hline F9 & $252 \pm 0.02$ & $5.3 \pm 0.07$ & $5.2 \pm 0.06$ & $0.69 \pm 0.056$ & $98.68 \pm 0.64$ & 61.55 \\
\hline F10 & $247 \pm 0.01$ & $5.3 \pm 0.08$ & $7.3 \pm 0.09$ & $0.49 \pm 0.098$ & $99.26 \pm 0.20$ & 64.54 \\
\hline F11 & $251 \pm 0.08$ & $5.1 \pm 0.09$ & $5.5 \pm 0.03$ & $0.54 \pm 0.067$ & $99.78 \pm 0.17$ & 58.75 \\
\hline F12 & $254 \pm 0.03$ & $5.2 \pm 0.06$ & $5.7 \pm 0.07$ & $0.57 \pm 0.024$ & $98.87 \pm 0.42$ & 59.42 \\
\hline F13 & $247 \pm 0.07$ & $5.1 \pm 0.04$ & $5.9 \pm 0.04$ & $0.72 \pm 0.074$ & $99.22 \pm 0.85$ & 59.54 \\
\hline F14 & $251 \pm 0.04$ & $5.1 \pm 0.07$ & $6.3 \pm 0.08$ & $0.64 \pm 0.067$ & $98.24 \pm 0.65$ & 59.73 \\
\hline F15 & $250 \pm 0.02$ & $5.1 \pm 0.07$ & $6.0 \pm 0.03$ & $0.68 \pm 0.023$ & $99.80 \pm 0.15$ & 52.45 \\
\hline F16 & $245 \pm 0.08$ & $5.1 \pm 0.05$ & $7.8 \pm 0.06$ & $0.53 \pm 0.056$ & $98.39 \pm 0.93$ & 56.21 \\
\hline
\end{tabular}

*The values represent mean $\pm S . D ; n=3, F C=$ Formulation Code 


\section{Evaluation of post-compressional parameters of tablet} characteristics

Thickness was in range of $5.1 \pm 0.04$ to $5.3 \pm 0.09$. The hardness of tablet was measured on Pfizer hardness tester. The hardness was in range of $4.2 \pm 0.03$ to $8.6 \pm 0.04 \mathrm{Kg} / \mathrm{cm}^{2}$. The weight $(\mathrm{mg})$ of each of 20 individual tablets was determined by dusting each tablet off and placing it in an electronic balance ${ }^{25}$. The weight data from the tablets were analyzed for sample mean and percent deviation. The friability was in range of $0.39 \pm 0.039$ to $0.72 \pm 0.074$. Drug content was in range of $98.24 \pm 0.65$ to $99.80 \pm 0.15$ indicating good content uniformity in the all formulations. The swelling index was in range 31.08 to 64.54 . F10 tablet formulation having higher swelling index. All the postcompression parameters results were within limit of IP. The post-compression results are summarized in table 3 .

\section{In-vitro buoyancy and lag time study}

The floating lag time shows in table 4. All the formulation from F1 and F5 did not float this was may be due to lower the percentage of gas generating agent. Some formulations exhibit good lag time but dissolved very rapidly. The in-vitro buoyancy shows in table 4. For the formulation F4, F15, F16 the duration of buoyancy was more than $24 \mathrm{hrs}$ and less lag time 21 to $24 \mathrm{sec}$, the floating capacity increased in these formulations and floated with less lag time due to high concentration of gas generating agent sodium bicarbonate and citric acid induced carbon dioxide generation in the presence of dissolution medium.

Table 4: Floating ability of various CGPS Lafutidine tablets formulation

\begin{tabular}{|c|c|c|}
\hline FC & Floating Lag time (sec) & Floating duration(hrs) \\
\hline F1 & Do Not float & Do Not float \\
\hline F2 & 29 & 24 \\
\hline F4 & 25 & 24 \\
\hline F5 & 24 & 24 \\
\hline F6 & Do Not float & Do Not float \\
\hline F7 & 373 & 24 \\
\hline F8 & 158 & 24 \\
\hline F9 & 880 & 24 \\
\hline F10 & 69 & 24 \\
\hline F11 & 54 & 24 \\
\hline F12 & 270 & Dissolved \\
\hline F13 & 236 & Dissolved \\
\hline F14 & 223 & Dissolved \\
\hline F15 & 300 & Dissolved \\
\hline F16 & 22 & 24 \\
\hline & 21 & 24 \\
\hline
\end{tabular}

*The values represent mean $\pm S . D ; n=3, F C=$ Formulation Code
The gas generation is trapped and protected within the gel formed by hydration of polymer thus decrease in the density of tablet. It was observed that paddle speed affected the floating property of tablet. However some results revealed that concentration of HPMC K4M and Trigonella foenum mucilage increased total floating time and decreased lag time. This is increased because of increased gel strength of matrices, which prevents escape of evolved carbon dioxide from matrices leading to decreased density of the formulations. As the density of tablet falls below 1 the tablet become buoyant. The result shows that the amount of HPMC K4M increased along with Trigonella foenum mucilage increased TFT due to increased matrix integrity at high amount of HPMC K4M and Trigonella foenum mucilage. While amount of sodium bicarbonate and citric acid increases TFT decreases because both gas generating agents promote faster erosion of tablet.

\section{In-vitro drug release study}

From in-vitro drug release study it is found to be as the concentration of the polymer increases the drug release decreases. From the result the formulations containing large concentration of high viscosity polymer such as HPMC K4M and Trigonella foenum mucilage induced formulation of strong viscous gel layer that leads to decreased water diffusion into the tablet. This results in decreased drug release. The detailed in-vitro data were plotted for percentage drug released Vs time. The drug release profiles were shown in figures 6-9. But the drug release profiles of formulations F11-F14 not showed because within 2 hours complete drug released. For the formulation F4, F15, F16 as the polymer concentrations increases the drug release decreases and promote faster erosion of tablet. The gas librating agent like citric acid and $\left(\mathrm{NaHCO}_{3}\right)$ increased in the tablet formulations the drugs release is also increases and at the same time floating lag time decreases. $\mathrm{NaHCO}_{3}$ has principal outcome for buoyancy lag time, while HPMC along with Trigonella foenum mucilage has leading effect on total floating time (TFT) and drug release.

\section{In-vitro Release Study of CGPS Lafutidine Tablets}

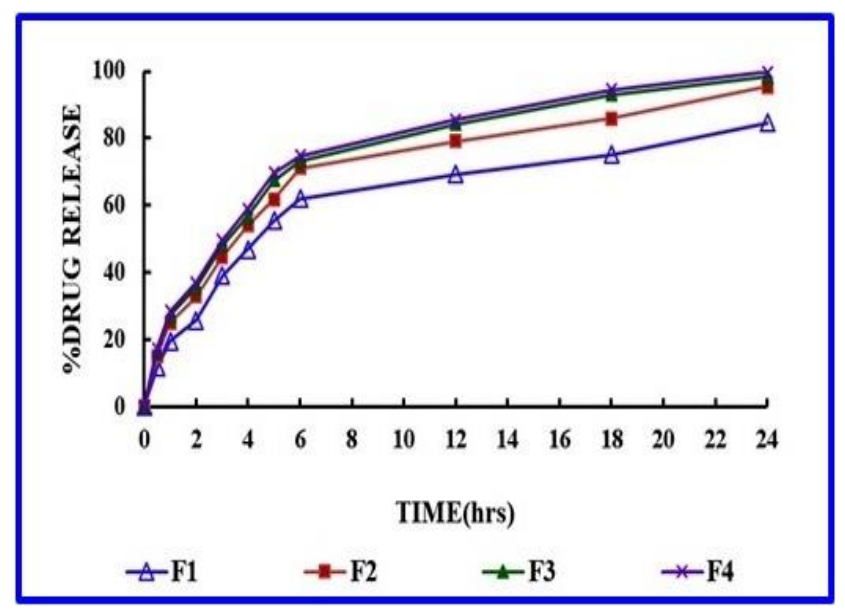

Figure 2: In-vitro drug release of formulation (F1-F4) 


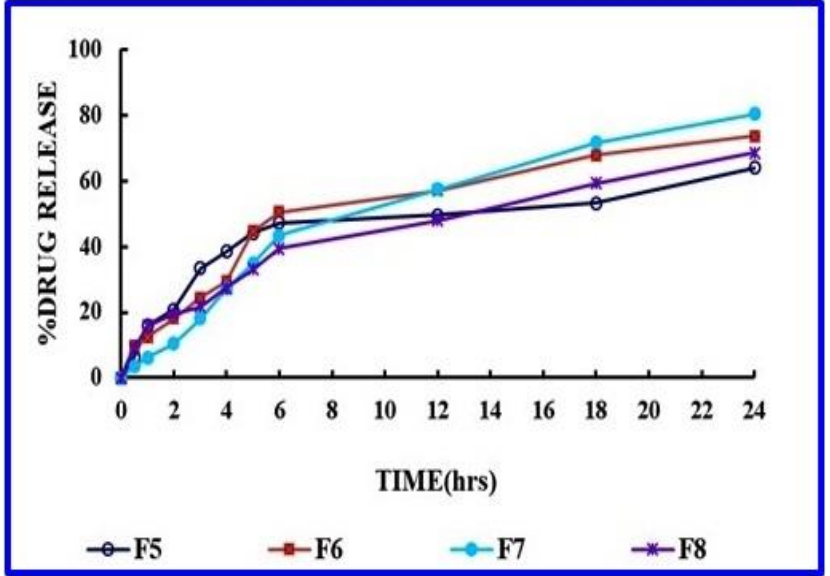

Figure 3: In-vitro drug release of formulation (F5-F8)

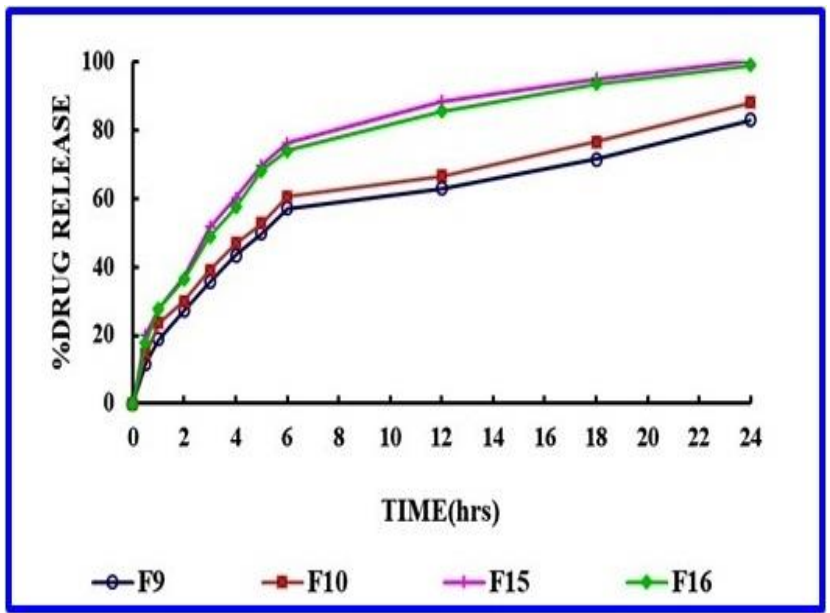

Figure 4: In-vitro drug release of formulation (F9-F16)

\section{Kinetic Study Information}

In the present study the aim was zero order drug release from the tablets and so that the diffusion coefficient was targeted to 1 . The dissolution data of optimized formulation fitted well into zero order release kinetics $\left(r^{2}=\right.$ 0.9876 ). The diffusion coefficient $(n)$ value ranges from 0.4472 i.e. Nearest to 1 indicated that floating tablets follow zero order kinetics of drug release. The mechanism of drug release in these cases was known to follow Fickian Diffusion (Higuchi Matrix). The best and optimized formulation F16 follows zero order kinetics was with Fickian Diffusion (Higuchi Matrix) mechanism release.

\section{CONCLUSION}

From the present study, the HPMC K4M along with the combination of Trigonella foenum mucilage used as release retardant and floating agent. The results indicated that Trigonella foenum with HPMC K4M effectively controlled release for $24 \mathrm{hrs}$ and Floating lag time was $21 \mathrm{sec}$. Floating lag time was observed in best formulations F4, F15 and F16 which shows 24, 22, $21 \mathrm{sec}$ respectively and duration of floating was nearly about $24 \mathrm{hrs}$ and all most $99 \%$ drug released within $24 \mathrm{hrs}$. From study it is evident that a promising gas powered controlled release floating tablets of Lafutidine can be developed to increase gastric residence time and thereby improve the therapeutic effect of the drug. From the study, it was concluded that natural release retardant ie. Trigonella foenum mucilage with HPMC K4M showed good release retardant and floating as compared to that of other synthetic floating agent. Hence Trigonella foenum mucilage can be used in maximum concentration as it shows different characteristic i.e. non toxic, biocompatible, bio-degradable, no side effect.

\section{REFERENCES}

1. Sameer Singh, Kalpana Prajapati, A K Pathak, A Mishra, International Journal of Pharm Tech Research CODEN (USA): IJPRIF. Jan- Mar 2011;Vol.3, No.1:333-341.

2. Horoshi S,Yasuhiko M, Toshio O, Masaharu M, Hisakazu S. Dissolution Mechanism of Diclofenac Sodium from wax matrix granules. J Pharm Sci 1997; 86: 929 -932.

3. Raghavendra Rao NG, Harsh A Panchal, Pentewar Ram. Formulation And In-Vitro Evaluation Gastroretentive Drug Delivery System Of Cefixime For Prolong Release. Der Pharmacia Sinica, 2011, 2 (2):236-248.

4. Devesh Kapoor; Asian Journal of Biomedical and Pharmaceutical Sciences 2012;2(9):1-10.

5. Lingam Meka, Bhaskar Kesavan, Krishna Mohan Chinnala, Venkateswarlu Vobalaboina, and Madhusudan Rao Yamsani AAPS Pharm SciTech. 2008 June; 9(2): 612-619.

6. Subal CB, Floatable Gastroretentive Emerging potential. Pharmabiz. Oct 2005.

7. Hemanth Sahu, Vivek Jain, Niraj Upmanyu, Subhendru S Mishra and Navdeep Raghuwanshi. "Formulation and Evaluation of Effervescent Floating tablet of Levofloxacin". Scholars Research Library. Der Pharmacia letter 2011;3(6):272-279.

8. Lokendra Pal Singh, Rajesh KS, Deepak G Umalkar, Vijay Kumar Chauhan, Viral Kumar Rana, Kamini S Vasava. Floating Effervescent Tablet: A review Journal of Pharmaceutical and Biomedical Sciences 2011;5(11).

9. Deshpande $\mathrm{AA}$, Shah $\mathrm{NH}$, Rhodes $\mathrm{CT}$ and Malick W. Development of a novel controlled release system for gastric retention. Pubmed gov Pharm Res.1997 Jun;14(6):815-819.

10. Dutta AC. Botany. 6th edn. Oxford University Press, Calcutta $1995 ; 134$.

11. Evans WC, Tease and Evans. Pharmacognosy. 14th edn, Harcourt Brace \& Co., Asia Pvt. Ltd, Singapore. 1996; 196, 208, 209, 213-215, 462, 555.

12. The Wealth of India: A Dictionary of Indian Raw Materials and Industrial Products Raw Materials Series. Publications and Information Directorate, CSIR, New Delhi. Revised series, A 1985; Vol 1:43-44, 148.

13. Newman AW. Micromeritics: Brittain HG; Physical Characterization of Pharmaceutical Solids. Marcel Dekker Inc, New york; Basel, 1995; 70: 293-294.

14. Newman AW. Micromeritics: Brittain HG; Physical Characterization of Pharmaceutical Solids. Marcel Dekker Inc, Newyork; Basel, 1995; 70:271-275.

15. Wells J. Pharmaceutical Pre-formulation: Aulton ME; Pharmaceutics: The Science of dosage form design. 3rd edi, Edinburg, London, Melbourne, New york, 1998; 247. 
16. Laxmi Kumari Sah Teli, Yogita Tyagi, Raghavendra Rao NG. Formulation and Evaluation of Lafutidine Loaded Fast Dissolving Tablet Using Trigonella foenum. Indian Journal of Research in Pharmacy and Biotechnology (IJRPB) 2020; Vol 8, Issue 3:May 1-9.

17. Raghavendra Rao NG, Vijaya Kumar G, Akhlaaq Ahmad. Formulation and Evaluation of Gas Powered System of captopril tablets. American Journal of Pharmacy and Health Research. AJPHR: 2015; 3(9):40 - 56.

18. Raghavendra Rao NG, Vijaya Kumar G, Priyanka V. Design and Development of Niveripine Gas powered systems for controlled release. Asian Journal of Biochemical and Pharmaceutical Research. AJBPR. 2015; 5(3):146-157.

19. Raghavendra Rao NG, Laharika M, Kistayya C. Design and Development of Simvastatin Gastroretentive Tablets for Controlled Release. Journal of Drug Delivery and Therapeutics (JDDT) 2017; 7(1):30-36.

20. Banker GS, Anderson NR. Tablets. The theory and practice of industrial pharmacy; Lachman, L, Lieberman HA, Kanig JL, Eds., 3rd; Varghese Pub. House: Bombay, 2003, 299-300.

21. Rao BP, Neelima AK, SnehithVS, Ramesh C. Development of Gastroretentive Drug Delivery System of Cephalexin by using Factorial Design. Ars Pharma, 2009;vol.50:8-24.

22. Sharma MC, Sharma S, Kohli DV, Chaturvedi SC. Formulation In-vitro Evaluation, study of effect of Hardness on Buoyancy the time of Gastroretentive Film and Floating Tablet. Journal of Optoelectronic and Biomedical Materials Dec 2009; Vol 1:pp353-358.

23. Mehta K, Patel NK, Ganatra MH, Patel TD, Patel NJ. Formulation and Optimization process of Gastroretentive Floating Tablets of Ondansetron HCL. JPRHC, 2018; Vol.2, issue 3:253-257.
24. Yash Paul, Manoj Kumar and Bhupinder Singh. "Formulation and in-vitro evaluation of Gastroretentive drug delivery system of Cefixime Trihydrate". Int. J. Drug Dev. \& Res., OctDec 2011; 3(4): 148-161.

25. Ziyaur R, Mushir A, Khar RK. Design and evaluation of bilayer floating tablet of Captopril. Acta Pharma. 2006; 56:49-57.

26. WellsJ. Pharmaceutical Preformulation. Pharmaceutics: The Science of Dosage Form Design. ME Aulton. Eds, 3rd, Edinburgh London: Melbourne and New York, 1988, 235,248.

27. Ganesh S, Radha krishina M, Ravi M, Prasanna Kumar B, Kalyani J. In-vitro Evaluation of the effect of combination Hydrophilic and hydrophobic polymers on Controlled Release Zidovudine Matrix Tablets. IJPS.Nov.2003.

28. Raghavendra Rao NG, Pentewar Ram, Bussetti SS. Formulation and Evaluation of Gas Powered Systems of Cefixime Tablets for Controlled Release. Int. Journal of Pharm Bio Sci, 2010; Vol.1 (2):18-22.

29. Wells J. Pharmaceutical Pre-formulation. Pharmaceutics: The Science of Dosage Form Design. ME Aulton. Eds., 3rd, Edinburgh London: Melbourne and New York, 1988, p 247.

30. Higuchi T. Mechanism of sustained-action medication. Theoretical analysis of rate of release of solid drugs dispersed in solid matrices, J. Pharm. Sci., 1963;51:1145-9.

31. Costa P, Lobo JMS. Modelling and comparison of dissolution profiles, Eur. J. Pharm. Sci., 2001; 13:123-33.

32. Nur AO, Zhang JS. Captopril floating and bioadhesive tablets: design and Release kinetics. Drug Dev Ind. Pharm 2000; 26:965-69.

Source of Support: None declared.

Conflict of Interest: None declared.

For any question relates to this article, please reach us at: editor@globalresearchonline.net New manuscripts for publication can be submitted at: submit@globalresearchonline.net and submit_ijpsrr@rediffmail.com 